\title{
The impact of possible-offer
} announcements on the wealth effect of target firms

Article

Accepted Version

Li, H. and Zhou, D. (2019) The impact of possible-offer announcements on the wealth effect of target firms. European Journal of Finance, 25 (15). pp. 1440-1461. ISSN 1466-4364 doi: https://doi.org/10.1080/1351847X.2019.1601120 Available at https://centaur.reading.ac.uk/82850/

It is advisable to refer to the publisher's version if you intend to cite from the work. See Guidance on citing.

To link to this article DOI: http://dx.doi.org/10.1080/1351847X.2019.1601120

Publisher: Taylor and Francis

All outputs in CentAUR are protected by Intellectual Property Rights law, including copyright law. Copyright and IPR is retained by the creators or other copyright holders. Terms and conditions for use of this material are defined in the End User Agreement.

www.reading.ac.uk/centaur

\section{CentAUR}


Central Archive at the University of Reading

Reading's research outputs online 


\section{The Impact of Possible-Offer Announcements on the Wealth Effect of Target Firms}

Hang Li*, Dan Zhou**

* Birmingham Business School, University of Birmingham, Birmingham, United Kingdom

** Department of Business Informatics, Systems and Accounting, Henley Business School, University of Reading, Whiteknights, Reading, United Kingdom

Corresponding: Hang Li, hxl445@alumni.bham.ac.uk

Acknowledgements: We are grateful to the editor and anonymous referee for their helpful comments and suggestions. Usual disclaimer applies. 


\section{The Impact of Possible-Offer Announcements on the Wealth Effect of Target Firms}

The stock market materially and positively responds to released information on possible offers, likely because such announcements signal the high probability that formal bids will be offered. If potential takeover discussions are revealed earlier, then target shareholders will gain significantly lower abnormal returns around the time of when formal offers are announced. Financial bidders are less likely to approach targets with earlier possible offers; however, if they do offer possible takeovers, they need to pay incrementally higher bid premiums in their formal offers. The reform inherent in the UK Takeover Code of 2011 weakens a bidder's willingness to offer possible takeovers. The pre-reform effects of possible offers on the wealth effect of targets differ from those seen after the reform.

Keywords: Mergers and acquisitions; Possible offer; Natural experiment; Financial bidder; Wealth effect

JEL classification: G34; G38 


\section{Introduction}

Before formal deal announcements, possible takeover discussions may be acknowledged by bidders, targets, or both. The literature that focuses on information leakage about, or rumors of, takeovers largely overlooks informal takeover announcements, or combines rumors with informal takeover announcements (Aktas, de Bodt and Roll 2010; Ahern and Sosyura 2014). Mulherin and Simsir (2015) were the first researchers to suggest that in the absence of considerations of merger-related events (e.g., rumors, financing information, and informal takeover announcements), estimates of target firms' abnormal returns are biased. However, it is difficult to interpret the general impact of combined merger-related events, as they contain complicated information that may have varied effects on the market's anticipation of a formal bid and the target stock price. A possible offer is publicly accessible information explicating the possible takeover discussion between bidders and targets. Unlike rumors on takeovers, the release of a possible offer by bidders, targets or both may systematically improve the market's anticipation of the likelihood of a formal takeover offer announcement, so that the stock market responds positively to this announcement. Research on the role of possible offers in the context of US or UK markets has been scarce. To provide a clearer interpretation of the role of possible offers, the current study isolates the effect of possible offers from other merger-related events and investigates how possible-offer announcements influence the wealth effects on target firm shareholders during the negotiation period.

A newly added clause in the updated UK Takeover Code of September 2011namely, the 28-day 'put-up or shut-up' (PUSU) period—specifically restricts the behavior of bidders who approach target firms to make initial possible offers. It requires that this type of bidder express its formal bidding intention within 28 days of a possible- 
offer announcement. If a bidder eventually states no intention of bidding within those 28 days, then that bidder must not approach the same target again in the subsequent six months (Takeover Panel 2011). ${ }^{1}$ This reform highlights the role of a possible offer in deal negotiations. As such, we are able to examine the effects of possible offers on the wealth gains of targets, based on a natural-experiment environment created by virtue of the 2011 reform.

We start our investigation into the role of possible-offer announcements by examining the likelihood that these announcements will occur. We identify financial bidders and the 28-day PUSU reform as the important determinants of possible-offer announcements. Gorbenko and Malenko (2014) observe that, compared to strategic bidders, financial bidders (mainly private equity [PE] firms) with expertise in firm valuation and deal negotiation are less likely to offer both informal and formal bids. Fund information reports disseminated by PE firms are voluntary (Kaplan and Schoar 2005); given this fact, PE firms are able to approach targets more secretively and avoid the potential (and intensive) competition that would have occurred had potential takeover discussions been revealed earlier. After the 28-day PUSU period, bidders may be more cautious in choosing to disclose potential takeover discussions, because should the bidding not be made firm within 28 days, they then bear the risk of needing to step aside for six months. Using manually collected data, we find that financial bidders are significantly less likely to announce possible offers; additionally, in the post-reform period, the likelihood of a possible-offer announcement is even significantly lower.

We then investigate separately how the stock market responds to possible-offer announcements and to formal offers. Among the sample of 990 takeovers, we observe 409 deals for which there were earlier possible offers. Comparing the three-day offerannouncement returns around possible-offer announcements (22.69 percentage points) 
and formal-offer announcements (15.65 percentage points), we find that, on average, the market response to a possible-offer announcement is strikingly more positive than that to a formal-offer announcement. This could be due to a higher level of anticipation for subsequent formal bids. By matching the dates of formal-offer announcements for deals with possible offers and those without possible offers, ${ }^{2}$ we find that target shareholders generate significantly more abnormal returns around the date on which possible offers are announced.

Financial bidders tend to acquire undervalued firms that have growth potential, while strategic bidders pay more attention to post-takeover synergies (Gorbenko and Malenko 2014). On account of this difference, the stock market may respond distinctively towards announcements of possible and formal offers; therefore, we also explore the potential difference in the wealth gains of target shareholders, between deals with financial and strategic bidders. After interacting the indicator of possible offers with the indicator of financial bidders, the regression results show that the shareholders of the target firm gain even higher returns around the time of a possible-offer announcement if the bidder is a financial firm. We assert that financial bidders associated with a lower likelihood of revealing possible-offer discussions impose a stronger shock to the stock market when they disclose possible offers in reality.

When examining the wealth gains around the dates of formal announcements, interestingly, we observe significantly less wealth gains during this event window in cases where a possible offer had already been released. The earlier results suggest that stock returns surge around the time of possible-offer announcements. By combining these two findings, we attribute the relatively low returns around the formal announcement dates to the fact that formal offers that follow revelations of potential takeover discussions impose weaker shocks on the stock market around the time that a 
formal bid is offered. Additionally, we note that financial bidders that approach target firms with initial possible offers do not have an incremental impact on shareholders' wealth gains associated with formal offers.

Earlier price run-ups prior to the offer of a formal bid may lead to higher offer premiums (Schwert 1996; 2000). Although earlier and more furious price increases around the dates of possible-offer announcements do not happen in the immediate runup to a formal-offer announcement, they may also contribute positively to the offer premiums that the targets can receive. Therefore, we investigate whether the announcement of a possible offer benefits the target shareholders by increasing the bid price so as to enhance bid premiums. Our results show that the offer of possible takeovers significantly and positively contributes to improvements in offer premiums, irrespective of first and final-bid premiums. Given their relatively lower level of concern about synergies relative to strategic bidders, financial bidders tend to offer lower prices during target acquisition (Gorbenko and Malenko 2014). Interestingly, the results indicate that target firms receive even higher bid premiums if they are approached by a financial bidder with a possible offer prior to when the formal offer is made. Therefore, we further develop the interpretation that financial bidders are reluctant to disclose takeover discussions before a takeover announcement is made firm. Nevertheless, if possible offers are disclosed for deals with financial bidders, the stock market responds to the announcement more positively—likely because of stronger market shock and higher anticipated deal premiums.

In addition, empirical results show that target shareholder returns through either possible-offer or formal-offer announcements make no prominent difference in the prereform period; this remains true in the post-reform period. Estimation results with respect to the Kaplan-Meier hazard function suggest that the 28-day PUSU period 
effectively limits the length of the pre-public negotiation period during which the potential target is subject to the risk of being taken over. However, when splitting the full sample into two groups - which is to say, those before and after 2011, the year of the reform - the results demonstrate a structure break regarding the effect of possibleoffer announcements on the wealth effects of targets.

This study sheds light on the effect of possible offers announced prior to formal bids; this effect is seldom explored in the literature. We fill this literature gap by carefully examining the effects of possible offers on the wealth gains of target shareholders around possible-offer and formal-offer announcements. We also affirm that the release of a possible offer causes higher stock returns in the period leading up to the formal-offer announcement date, and this eventually leads to higher formal offer premiums. The current study is also the first empirical study to examine a financial bidder's likelihood of releasing official information with regard to possible takeover discussions. In addition, no sufficient research has yet empirically examined how the reform inherent in the Takeover Code of 2011 drives the effect of possible-offer announcements. The current study takes this regulatory change into account. Although the current study focuses on the UK takeovers market, it is also expected to contribute to the literature on the US context, where there is limited exogenous variation in antitakeover laws.

The remainder of this paper is structured as follows. Section 2 introduces the negotiation process for UK takeovers and the particulars of the 28-day PUSU clause. A literature review and hypotheses are provided in Section 3. Section 4 presents sample and descriptive statistics, and the main empirical results are presented in Section 5. Section 6 contains further analysis of the effect of the Takeover Code's regulatory 
change and aggregate economic conditions. Finally, Section 7 provides concluding remarks.

\section{The takeover negotiation process and 28-day PUSU period}

\subsection{The negotiation process}

Betton, Eckbo, and Thorburn (2009) develop a takeover process model to investigate toehold power in the negotiation procedure. They clarify two stages in the negotiation process for US takeovers - namely, private negotiation, followed by a public competitive procedure should that private negotiation fail. Boone and Mulherin (2007), in shedding light on the selling process (from the perspective of target firms), speak of the private takeover process that takes place prior to the public contest. In the private negotiation stage, the contacted bidders receive non-public information and promise not to announce an unsolicited deal (Hansen 2001). Studies in more recent years have gradually underscored the prevalence of informal bidding discussions prior to formaloffer announcements. For example, Aktas et al. (2010) find that latent competition during the entire deal negotiation including both private and public negotiation periods stimulates an increase in offer premiums. The entire deal negotiation starts from the date of the first merger discussion between the two parties (Ahern and Sosyura 2014). With regard to differences in the bidding strategies of strategic and financial bidders, Gorbenko and Malenko (2014) were the first to identify informal bids where potential offerors disclose their bid intentions. (In the current study, the term 'informal bid' refers to a possible offer.) In their sample, approximately one-third of bidders make informal bids, and strategic bidders tend to announce both informal and formal bids. Nonetheless, the true extent of causality between possible-offer announcements and the wealth gains of shareholders remains widely unexplored. 
Figure 1 shows the negotiation process for UK takeovers. We split the negotiation process into three stages. The period from the initiation of confidential deal communications to the possible-offer announcement date is defined as the "private negotiation stage.' During this period, rumors may emerge. The 'pre-public negotiation stage' occurs in the interval between the possible-offer announcement date and the formal-offer announcement date. Releasing a possible-offer announcement attracts the public awareness of the deal transaction. Once a formal offer is announced, the negotiation enters the 'public negotiation stage.' It is possible that no possible offer is published during the negotiation process; in this scenario, private negotiation is defined as taking place between the start of confidential negotiation communications and the date before the formal-offer announcement. Appendix B offers anecdotal evidence in terms of how a takeover document states the announcement of possible offers.

\subsection{8-day PUSU term}

Pre-emptive anti-takeover provisions are inhibited for UK takeovers, which in line with one of the principles affiliated to the UK takeover regime that target companies are not expected to frustrate a bid (Armour, Deakin, and Konzelmann, 2003). This sacrifices much of the bargaining power of the target side in a deal negotiation process, which is reflected by lower offer price and weaker benefits for target firms' managers and shareholders. The decree of the updated UK Takeover Code in September 2011 makes some material alterations to restrict the use of deal-protection devices. These changes aim to rebalance the bargaining power between targets and bidders by controlling the potential threats related to 'virtual bids' (Payne, 2011). The updated Takeover Code incorporates four new features: general inhibition of the use of target termination fees; the request to identify potential bidders at the beginning of the offer period; automatic 
28-day PUSU deadlines; and reinforced information disclosure in offer documents (Clifford Chance, 2011).

The 28-day PUSU clause requests bidders to clarify their current bid intention within 28 days since declaring possible offers. This aims at limiting the length of the pre-public negotiation period in which the potential target is subject to the risk of being taken over. If offerors acknowledge no bid intention within these 28 days, they need to stand away from the same target for the following six months. In this way, the price volatility around possible and formal offers of targets and bidders caused by information about possible offers may change accordingly. The 28-day PUSU also tends to improve the bargaining power of targets, as target firms can reject a request to extend the PUSU deadline or stop the offer talk if they are unsatisfied with the terms in a deal discussion.

\section{Literature review and hypotheses}

\subsection{The determinants of announcing possible offers}

A possible-offer announcement is an official statement from bidders and/or targets to acknowledge the discussion of a potential merger; this statement is typically made in response to recent rumors or stock price volatility. It is unlike a rumor or other type of information leakage. Rumors are normally considered a detrimental factor with respect to deal completion, deal valuation (Alperovych, Cumming, and Groh 2016), shareholder benefits (e.g., Ahern and Sosyra 2015; Leung and Ton 2015), and market efficiency (e.g., Han and Yang 2013). However, possible-offer announcements constitute public information disclosed by reliable sources (i.e., bidders and/or targets) that is expected to largely enhance market confidence with regard to following formal-offer announcements. 
Financial bidders, which are mainly PE firms, are more concerned about the growth opportunities of potential targets (Kester and Luehrman 1995) and tend to be relatively smaller firms (Renneboog, Simons, and Wright 2007). PE firms are more autonomous in their ability to choose the extent to which they release fund information. Hence, they are more likely to hold private negotiation information, to avoid attracting raiders. Additionally, financial bidders' professional expertise in firm valuation and deal negotiation (e.g., Gorbenko and Malenko 2014) may make them skillful in 'skipping' the process of announcing possible offers. In addition, only a few personnel from financial bidders are involved in pre-public negotiations (Alperovych et al. 2016), and so there is less of a likelihood that bid-preparation information will be leaked from financial bidders.

The reform of the UK Takeover Code in 2011 repeals certain deal-protection devices and tends to improve the target-side bargaining position for UK takeovers (Code Committee 2012). Martynova and Renneboog (2008) suggest that takeover waves are frequently driven by regulatory changes; therefore, the regulatory change inherent in the UK Takeover Code may influence the likelihood of being acquired and the ways of being approached. The 28-day PUSU clause limits the duration between possible-offer and formal-offer announcements, to control threats related to 'virtual bids' that are encountered by targets (Payne 2011). Hence, we put forward Hypotheses $1 \mathrm{a}$ and $1 \mathrm{~b}$, as follows.

Hypothesis 1a: Target firms are less likely to be approached through initial possible offers by financial bidders.

Hypothesis 1b: Takeovers are less likely to be initiated by possible offers in the post-reform period. 


\subsection{The effect of announcing possible offers}

Jarrell and Poulsen (1989) find that rumors of an impending bid in news coverage lead to prominent stock price run-ups in the period immediately leading up to the formaloffer announcement date. Rumors of takeovers through media can impede the negotiation progress. In such circumstances, both sides of the takeover transaction may reach an agreement to announce informal offers, in order to suppress any market volatility imposed by rumors. Alternatively, bidders may deliberately reveal discussions with current targets vis-à-vis a potential takeover announcement, if they feel that the target is reluctant to further negotiate the takeover transactions: bidders will put out unsolicited possible-offer announcements, and then expect that shareholders and other stakeholders of targets to exert pressure on the targets, if being acquired is a good choice from their perspective. In either case, possible offers may prompt more intensive competition from other potential competitors and give a precise signal to the stock market, so that the market considers the likelihood of formal bid later to be higher.

Previous studies document well how investors trade on precise and imprecise rumors, either of which can lead to movement in the stock price of target firms (Dennis and McConnel 1986; Bommel 2003). When investigating the returns and pricing of rumored target firms, Chou, Tian, and Yin (2015) find that larger abnormal returns around the date of a rumor's publication can signal a greater probability that the rumor will be followed by a formal bid. King (2009) shows that insiders trading on inside information trigger abnormal returns and abnormal turnovers of target firms prior to formal deal announcements. A possible offer delivers reliable information to the market, so that investors can trade on it; it also facilitates market anticipation regarding a higher probability of an upcoming solid bid. Hence, putting out a possible-offer announcement 
tends to significantly increase the target shareholder returns around the possible-offer announcement date.

Mulherin and Simsir (2015) expand the definition of 'original date announced' (ODA) to the date on which an initial merger-related event is released, and they compare the announcement returns around the newly defined ODA and the formal-offer announcement date. Our definition of 'possible-offer announcement date' is consistent with Mulherin and Simsir's (2015) definition of 'ODA.' We hand-collect the possibleoffer announcement date for each deal, if applicable, and examine the effect on stock returns of releasing possible-offer news; we do so after controlling for firm-specific and deal-specific characteristics. This multivariate analysis has not been executed in previous research.

Moreover, different types of bidders announce possible deals to send different kinds of information to the stock market. The market may react more strongly to possible-offer announcements by financial bidders, compared to those by other bidder types. As Renneboog et al. (2007) illustrate, when target firms are acquired by PE firms, the target's abnormal returns at one day prior to the deal announcement and 10 days around the deal announcement are 22.68 percentage points and 25.53 percentage points, respectively. Indeed, these returns are rather higher than the takeover returns of targets in a general context. ${ }^{3}$ Additionally, given that financial bidders are generally considered less likely to release possible offers, possible-offer announcements by financial bidders may impose a relatively stronger shock on the stock market. Hence, we put forward Hypotheses $2 \mathrm{a}$ and $2 \mathrm{~b}$, as follows.

Hypothesis 2a: Possible-offer announcements generate significantly higher wealth gains for target shareholders. 
Hypothesis 2b: Possible-offer announcements by financial bidders generate significantly higher wealth gains for target shareholders than do those by other bidders.

The traditional method of estimating the returns on a deal announcement does not consider the impact of offering a possible deal; this can lead to estimation bias on the target shareholder returns on a formal deal announcement (Mulherin and Simir 2015). For takeovers featuring possible offers, the stock price of targets may not overshoot to the formal-offer announcement, because there has been a market response captured by the stock price during the prebid period with the possible-offer announcement. In contrast, in the absence of an earlier disclosure of takeover discussions, a formal-offer announcement is expected to impose a stronger shock to the stock market, and this leads to higher formal-offer announcement returns to target firms.

From the perspective of information signals, information released by both targets and bidders help with mitigating adverse selection problems (Humphery-Jenner, Sautner, and Suchard 2017). By focusing on the signaling role of PE-backed takeovers, Humphery-Jenner et al. (2017) suggest that PE-backed acquirers with bidding experience and networks positively shape the market's anticipation of a deal's quality, especially when the targets are in poor-quality information environments. Ceteris paribus, if financial bidders announce possible offers before formal offers, then the stock market is expected to have a more optimistic response toward possible-offer announcements, relative to formal-offer announcements. In another words, the stock market is expected to be less shocked by formal takeovers undertaken by financial bidders. Hence, we put forward Hypotheses $3 \mathrm{a}$ and $3 \mathrm{~b}$, as follows.

Hypothesis 3a: Target's shareholders receive significantly lower wealth gains from formal deal announcements in takeovers with possible offers than in takeovers without possible offers. 
Hypothesis 3b: Target firms approached by financial bidders with initial possible offers experience significantly lower wealth gains through formal offer announcements.

The increase in target stock price in the pre-bid period may increase the bidding costs of bidders. Schwert (1996; 2000) suggests and supports the 'mark-up pricing hypothesis' by observing that bidders systematically mark up the offer price so that higher target run-ups lead to higher offer premiums. The market's anticipation of a formal offer is lifted by the announcement of a possible offer; this is one of the reasons why a price increases around the time of a possible-offer announcement. In the pre-bid period, shareholder returns are expected to strikingly increase around the time of the possible offer. Given this expectation, although the price increase did not occur in the period immediately preceding the date of the formal takeover offer, the offer premiums of takeovers with possible offers are expected to be higher when formal takeovers follow possible-offer disclosure.

As to the impact of financial bidders, because they have fewer concerns of posttakeover synergies, financial bidders are less willing to overpay. However, competition or latent competition during the negotiation period can boost the offer premiums (Aktas et al. 2010). To secure their fund management reputation, in cases where earlier takeover disclosure has attracted more intensive competition, financial bidders may therefore need to bid for higher premiums to secure the success of bids in formal takeovers. Therefore, we put forward Hypotheses $4 \mathrm{a}$ and $4 \mathrm{~b}$, as follows.

Hypothesis 4a: Possible-offer announcements prior to formal offers enable the target's shareholders to gain higher bid premiums.

Hypothesis 4b: Financial bidders make incremental and positive contributions to the relationship between possible offers and bid premiums. 


\section{Sample and descriptive statistics}

Takeovers announced from 2006 to 2016 in the UK are collected from the SDC Mergers and Acquisitions Database. The first criterion for selection is that all target firms should be publicly traded, while acquirers could be public firms, private firms or subsidiaries. Deals with target companies assigned to the finance and utility industries (Standard Industry Classification [SIC] code: 6000 to 6999 and 4900 to 4999) are excluded. We also request that the initial toehold plus shareholding sought by bidders needs to be higher than 50 percent of the total shareholding of the target firms. Deals announced by multiple bidders before the resolution of the first bid are identified as auctions. In this circumstance, only the first bidder's approach is included. 990 sample deals are collected after requesting all criteria above.

The SDC Platinum provides information on the date of a possible deal announcement and the number of days between the dates of informal the formal offers. However, Mulherin and Simsir (2015) indicate that the actual pre-merger activities is more than double the frequency of the events recorded in the SDC database. In this research, to overcome this potential problem caused by missing data, we manually collect the dates of possible offers where applicable and formal offers from the published documents recorded in the PI Navigator database. Compared with the accessible data reported by SDC, we also recognise that the SDC fails to capture all information about events of releasing possible offers and dates. ${ }^{4}$

Table 1 represents the yearly distribution of takeovers with and without possible offers. Of the 990 sample deals, 409 are initiated by a possible offer. The intensity of possible offers is calculated as follows: the number of takeovers with a possible offer scaled by the total number of takeovers in the corresponding year. Table 1 shows that the intensity of announcing possible offer decreases significantly from 2011 to 2012, which signals that the 28-day PUSU clause deter possible offers.

Firms' stock prices and accounting information are collected from the Datastream database. Deal-specific characteristics are collected from the SDC. To avoid the potential bias 
caused by missing observations in SDC (Moeller, Schlingemann, and Stulz, 2004), we look through the original documents on deal offers stored in PI Navigator and manually collect the initial and final offer prices to indemnify the completeness and accuracy of offer price records. 712 out of 990 sample deals have disclosed offer price based on our hand-collected data.

Table 2 shows the wealth gains on target shareholders for the full sample, and the subsamples of takeovers with and without a possible offer. The significance of statistical difference test for the mean (median) values of variables for takeovers with and without a possible offer is noted in the columns of the mean (median) values of takeovers without a possible offer.

Panel A of Table 2 shows the descriptive statistics of three-day CARs around the date of possible offer announcement. We measure wealth gains using cumulative abnormal returns (CARs) during the windows $[-1,+1]\left(\mathrm{CAR} \_3 \mathrm{DAY}\right)$ and $[-2,+2]\left(\mathrm{CAR} \_5 \mathrm{DAY}\right)$ around the date of possible offer announcements. On average, target shareholders improve their wealth gains by 22.69 percentage points. We then match the formal announcement dates for deals with and without possible offers. Panel A shows that 90 deals with possible offers can find corresponding deals without possible offers that are formally announced on the same day from the sample pool. When target firms are initially approached by possible offers, the average abnormal returns around the date of offering possible takeveors (26.88 percent) are significantly higher than those of other targets ( 7.94 percent). Whereas, targets initially approached by possible offers receive significantly less returns (13.26 percent) from formal offer announcement later.

Panel B of Table 2 demonstrates the univariate analysis of CARs around the date of announcing a formal offer and bid premiums. The calculation of deal announcement returns follows the standard estimation method. It equals the CARs during the window $[-1,+1]$ (CAR_3DAY) and $[-2,+2]($ CAR_5DAY) around the date of the formal deal announcements. The first (final) bid premium presented in Table 2 is calculated as the difference between the first (final) offer price and the target share price on 41 days before the formal deal 
announcement date scaled by the share price on 41 days before the formal offer announcement date (e.g. Betton et al., 2009).

Panel B presents on average, shareholders of target firms can generate 15.65 (16.46) percent CARs over a three-day (five-day) window around the date of announcing a formal deal. Target shareholders generate slightly higher CARs through formal deal announcement if no possible offer has been announced to public earlier. We also observe that, on average, the first and final premiums received by targets of takeovers with a possible offer are 30.37 percent and 32.89 percent respectively, which are slightly higher than those of takeovers without a possible offer. This slight difference is also shown when looking at the median value of bid premiums.

Table 3 presents the descriptive statistics for the firm-specific and deal-specific characteristics of the full sample and the subsamples with and without a possible offer. Similar as Table 2, the significance of statistical difference test of the mean (median) values of the variables for takeovers with possible offers and without possible offer is noted in the columns for the mean (median) values of takeovers without a possible offer. 43.03 percent of UK takeovers are initiated by financial bidders (FIN_BIDDER), which is higher than the proportion in Gorbenko and Malenko's (2014) study using US deals. The difference test shows that significantly fewer financial bidders announce possible offers compared with non-financial bidders. We observe that only 30.71 percent of takeovers in the full sample completed after 2011 (POST_REFORM). This implies that the reform in 2011 may effectively reduce the potential threat of a firm being taken over. Roughly 27.14 percent of sample takeovers are approached by possible offers in the post-reform period. This is significantly lower than the percentage of being targeted without a possible offer (33.22 percent). We also observe that takeovers with and without possible offers have no difference with regard of the size of target firm (TARGET_SIZE). Moreover, firms that are approached by an initial possible offer have a significantly lower previous sales growth (SALES_GROWTH) and liquidity ratio (LIQUIDITY), in addition to a higher operating performance measured by return on assets (ROA). 


\section{Main empirical results}

In this section, we present the regression results. We first explore the determinants of possible-offer announcements and, in particular, how financial bidders choose between possible-offer and formal-offer announcements. Following this, we exploit how the stock market responds to the release of possible offers and formal offers. As the choice of financial bidders in making possible offers (or not) conveys different information to the stock market, we also investigate the incremental contribution of financial bidders to the effects of possible offers on stock price. Finally, we investigate whether formal bid premiums are distinctively higher when potential takeover discussions are disclosed earlier through the media.

\subsection{Financial bidders and the likelihood of possible-offer announcements}

To investigate the likelihood that a possible offer will be announced, we use probit regression with the indicator of possible offers (POSSIBLE_OFFER) as a dependent variable, and the indicators of financial bidder (FIN_BIDDER) and postreform period (POST_REFORM) as independent variables of interest. We control for the target firm's size (TARGET_SIZE), age (AGE), average sales growth (SALE_GROWTH), Tobin's q (Q_RATIO), liquidity (LIQUIDITY), leverage (LEVERAGE), tangibility (TANGIBILITY), the standard deviation of return on assets (ROA_SD), HerfindahlHirschman Index (HHI), and the threat of being acquired (TAKEOVER_THREAT) ${ }^{5}$ (Ambrose and Megginson 1992; Harford, Humphery-Jenner, and Powell 2012; Bebchuk, Cohen, and Wang 2014). For the purpose of accounting for the time-invariant effects of the corresponding industry, we use the industry fixed effect based on the firm's two-digit SIC codes. Since the years featuring a high risk of being taken over (TAKEOVER_THREAT) and the post-reform period (POST_REFORM) capture the 
exogenous shock to the takeover market, we do not additionally control for the year fixed effect to preclude multicollinearity.

Table 4 presents the regression results of the likelihood of initiating a takeover through a possible-offer announcement, conditional on making a formal-offer announcement. In Table 4, the marginal effect of financial bidders indicates that they are 8.51 percent less likely to announce possible offers; this finding aligns with Hypothesis 1a. Financial bidders with strong expertise in searching for target firms and evaluating firm value are capable of making formal bids directly, so as to avoid early competitors. Alternatively, within a voluntary reporting system and with regard to fund information, financial bidders, especially PE firms, are more willing to withhold private negotiations until they decide to make a firm bid.

The significant and negative marginal effect of POST_REFORM shows that the likelihood of being approached with a possible offer is 12.14 percentage points lower than in the pre-reform period. This affirms the conjecture of Hypothesis $1 b$, and it suggests that the newly added 28-day PUSU clause in the updated Takeover Code limits the bidder's interests in approaching targets with earlier possible offers.

\subsection{Deal announcement returns through possible offers}

Table 5 presents the regression results for the effects of possible offers and financial bidders on the abnormal returns around the possible-offer announcement date. These regressions use the matched sample with or without possible offers, but while announcing formal offers on the same dates. Hence, 180 takeovers are used for the examination. All controls including those for year and industry fixed effects are employed. The material and positive coefficient of POSSIBLE_OFFER indicates that target firms generate significantly higher abnormal returns by putting out an 
announcement of potential takeover discussions; this supports Hypothesis $2 a$. In economic terms, by announcing possible offers, the deal announcement returns of the targets increase by 15.07 percentage points. In conjunction with the mean value of the three-day CARs around the possible offers (Table 2), the impact of possible offers is both economically and statistically significant. However, the insignificant coefficient of FIN_BIDDER indicates that being approached by a financial bidder does not lead to a strikingly different market response.

In Model 2 of Table 5, we investigate the incremental effect of financial bidders on the relationship between possible offers and shareholder returns, using the difference-in-difference (DiD) methodology. Thus, we introduce the interaction between the indicators of possible offers and of financial bidders (POSSIBLE_OFFER*FIN_BIDDER). As presaged in Hypothesis $2 b$, the positive and significant coefficient before the interaction illustrates that when possible takeovers are negotiated with financial bidders, target shareholders can yield significantly higher CARs around the time of the possible-offer announcement. Economically, deals involving financial bidders with possible offers gain additionally higher abnormal returns by 12.56 percentage points, compared to other types of deals. Since financial bidders are not supposed to release possible takeover discussions before a firm bid is made, the market may experience a stronger shock whenever bidders announce possible offers; this in turn causes higher stock price volatilities.

\subsection{Deal announcement returns through formal offers}


Table 6 presents the regression results for the effects of possible offers and financial bidders on abnormal returns around the formal-offer announcement date. All controls including year and industry fixed effects are employed.

Model 1 of Table 6 presents the effects for the full sample. The significantly negative coefficient on POSSIBLE_OFFER suggests that target shareholders obtain significantly lower wealth gains when a formal announcement follows a possible-offer announcement. Economically, targets with possible offers, on average, generate lower deal announcement returns by 3.92 percentage points, compared to their counterparts. Together with the positive association between a possible-offer announcement and the shareholder returns around the time of the possible-offer announcement, our interpretation is that, due to the earlier reaction of the stock market to the possible-offer announcement, the stock market has less resilience when the formal offer is eventually announced. This also underscores the cogency of the opinion that one should consider a possible offer a strong signal of an eventual formal bid, so that the announcement of a formal offer is not as surprising to the stock market as it would have been in the absence of this strong signal. These results support Hypothesis $3 a$. According to the insignificant coefficient of FIN_BIDDER, there is no prominent difference in the offer announcement returns of takeovers undertaken by financial bidders and those undertaken by strategic bidders.

Model 2 in Table 6 shows the DiD regression results based on the matched sample. To control for the potential endogeneity caused by the firm's decision to announce a possible offer, we use the propensity score matching (PSM) methodology ${ }^{6}$ to match takeovers with a possible offer (409 deals) and takeovers without a possible offer. The matching variables are target firm size (TARGET_SIZE), market-to-book ratio (Q_RATIO), firm leverage (LEVERAGE), a financial bidder dummy 
(FIN_BIDDER), and deal announcement year. The mean value of the percentage bias after matching is less than 5 percentage points. Based on the matched sample, we construct the DiD regression by employing the interaction between the indicators of possible offer and financial bidder. The insignificant coefficient before the interaction (POSSIBLE_OFFER*FIN_BIDDER) indicates no striking additional effect of financial bidders on the relationship between possible offers and CARs. Hence, Hypothesis $3 b$ is not supported. All results in Tables 5 and 6 are robust when CARs are measured in terms of the five-day event window around the deal announcement (unreported).

\subsection{Offer premiums}

According to the mark-up pricing hypothesis, higher pre-bid target price run-ups are expected to increase the offer premiums that target firms receive as a part of formal takeovers. The aforementioned results demonstrate higher abnormal returns around the possible-offer announcements generated by possible offers. Although this price increase is not in the run-up period immediately preceding the formal-offer announcement date, it still very possible to influence the formal bid price. Therefore, we examine whether possible offers that prompted earlier target shareholder returns increase the bidding costs (i.e., measured by higher bid premiums).

Table 7 presents the regression results of the effects of possible-offer announcements and financial bidders on bid premiums; Panel A (Panel B) features those with dependent variables of initial (final) bid premiums. The control variables accord with those used in previous studies that investigate the determinants of deal premiums (e.g., Schwert 2000; Moeller et al. 2004; Betton et al. 2014). In line with the measure used by Betton et al. (2009), when running regressions, the first (final) bid premiums are calculated via the natural logarithm of the ratio of the first (final) offer 
price and the target share price in the 41 days prior to the formal-offer announcement date. Model 1 in Panel A shows a significantly positive coefficient on POSSIBLE_OFFER. When the target side can negotiate for a higher price, the first-bid premiums increase by 21.74 percentage points, relative to the others. The result implies support of Hypothesis $4 a$ - namely, that for offerors, higher prebid stock returns lead to higher bidding costs. Moreover, the negative (albeit insignificant) coefficient of financial bidders indicates that financial bidders tend to be capable of arguing for a relatively low offer price. However, the price difference between financial bidders and strategic bidders is limited. When using financial premiums in Model 1 of Panel B, the results are fairly consistent.

Model 2 in Panel A presents the joint effect of possible-offer announcements and financial bidders (POSSIBLE_OFFER*FIN_BIDDER) on first premiums, using the DiD model. We employ PSM to match deals initiated by possible offers with deals initiated solely by formal offers. ${ }^{7}$ The significant and positive coefficient before the interaction term indicates that financial bidders who choose to approach target firms with possible offers need first to pay significantly higher bid prices than those who bid solely through formal offers. This implies that the public disclosure of possible offers by financial bidders has incremental benefits for the target side of takeovers, by enabling the target side to argue for a relatively high offer price. The higher premiums paid by financial bidders may be further explained by the fact that earlier disclosures of takeover discussions attract investors' trade in the information and higher deal competition in the pre-public negotiation period; however, given their concerns regarding their own fund management reputation, financial bidders may choose to bid with higher costs, even though they are less willing to. 
When shedding light on final premiums (Model 2 in Panel B), we also note that for takeovers where a financial bidder announces its possible bid interests before making a formal bid, the shareholders of the target firm tend to receive significantly higher final premiums, irrespective of whether the first bidders eventually pay the final price. Hypothesis $4 b$ is supported by these results.

In the regressions in Tables 5-7, we control for the post-reform period (POST_REFORM). We find that the reform inherent in the Takeover Code of 2011 significantly influences neither the target shareholder returns nor the bid premiums. These findings align with those of Restrepo and Subramanian (2017), who are skeptical of the efficiency of the reform inherent in the Takeover Code.

\section{Further analysis}

Substantial changes were made in September 2011 to the UK Takeover Code; those changes sought to rebalance the bargaining power between targets and bidders in deal negotiations. One of the newly added clauses in the regulatory change is the 28-day PUSU period, which exclusively constrains the behavior of offerors who initially approach targets with possible offers. Our aforementioned results demonstrate that in the post-reform period, the probability of a takeover drops markedly when an earlier possible-offer disclosure had been made. These results alone, however, cannot affirm the reform's effect on the wealth gains of target shareholders. In this section, we first directly compare the pending periods for target firms before and after the reform, by plotting the estimated Kaplan-Meier hazard function (i.e., the risk of being made a formal offer). ${ }^{9}$ Subsequently, to account for the potential structure break in this naturalexperiment environment, we investigate the role of possible offers on the wealth effects of targets in each of the pre-reform and post-reform periods. 
Additionally, the financial bidders' willingness to pay depends on the state of aggregate economic conditions (e.g., Gorbenko and Malenko 2014). When financial bidders are highly valuated, the cost of debt is lower when calculated by the credit spread. Therefore, we are interested in exploring how macroeconomic conditions affect the premiums paid by financial bidders.

\subsection{The Reform in the Takeover Code of 2011}

Figures $2 \mathrm{a}$ and $2 \mathrm{~b}$ present the hazard failure rate in the days following a possible-offer announcement, using deals made before and after the reform. Prior to the regulatory change, the maximum days in the pending period from the possible offer to the formal offer is 1,156 days (approximately four months). The hazard failure rate surges during the first 250 days following the possible offer; this means that, in the first 250 days, target firms are most likely to end the pending period by receiving a formal offer. However, some firms still suffer from a long period of hesitation, which ceases when they receive a final formal offer; this potentially influences, somewhat detrimentally, the daily operations of the target firms. Turning to the post-reform takeovers, we find that the maximum number of days in the pending period is 330 days. Compared to that seen in the pre-reform takeovers, the length of this period is effectively limited by the 28-day PUSU clause. Moreover, Figure 2b shows that after the reform, in the first 50 days, many target firms receive formal offers. From about 50 days after the possibleoffer announcement, the rate at which the hazard failure rate increases gradually attenuates.

When revisiting the role of possible offers on offer announcement returns and bid premiums both before and after the year of reform, some interesting results emerge. Panel A of Table 8 presents the effects of possible offers on shareholder returns around 
the time of formal-offer announcements and bid premiums, using pre-reform takeovers. In Models 1, 2, and 3, the dependent variables are the CARs around the formal-offer announcement date, first-bid premiums, and final-offer premiums, respectively. Model 1 of Panel A suggests that CARs are not significantly lower if possible offers are released in an earlier stage. The striking and positive coefficients of POSSIBLE_OFFER in both Models 2 and 3 consistently demonstrate that in the years prior to the reform, the takeover bidders who reveal earlier potential takeover discussions needed to offer higher bid premiums.

Panel B of Table 8 repeats these regressions, using post-reform takeover data. ${ }^{8}$ Model 1 of Panel B shows that target shareholders gain significantly lower CARs if possible offers are announced in advance of formal offers. Models 2 and 3 of Panel B suggest that in the post-reform period, the bid premiums of takeovers with possible offers, irrespective of first or final-bid premiums, are not very different from those of takeovers lacking possible offers. This suggests that in the years following the reform, bidders have become more cautious about announcing potential takeover discussions, so as to avoid bidding for higher premiums. There may be two substantial reasons for the lower CARs that correspond to the formal takeover announcements. First, as explained above, earlier possible offers signal to the market a higher likelihood of a formal bid being offered, and so the market sustains less shock when a formal offer is eventually released. Second, in comparing the relationship between premiums and possible offers in Panels A and B of Table 8, for the post-reform periods, we can to some extent attribute the significantly lower CARs around the formal offers to the relatively lower premiums. Overall, our results suggest a time-variant structure break with regard to the function of offering possible bids. 
Additionally, we note that in the 28 days prior to a formal-offer announcement, certain corporate behavior, such as sales and purchases of assets and market manipulation through rumor and information leakage. These activities may affect target firms' price volatilities and takeover outcomes. For instance, Cumming et al. (2016) find that the presence of market manipulation (including both end-of-day price dislocation and information leakage) reduces both the deal completion rate and the premiums that the target receives. In contrast, our results indicate that automatic and official disclosure of possible takeover discussions increase the premiums paid to the target. This finding empirically supports the natural difference between possible-offer announcements and market manipulation.

\subsection{Financial bidders and aggregate economic conditions}

Aggregate economic conditions are measured by the credit spread (Gorbenko and Malenko 2014). Like Gorbenko and Malenko (2014), we use the difference between the average 10-year yield of UK Benchmark AAA bonds in the last year of the deal announcement and the average 10-year UK Government Stored yield in the same period as the measure of the credit spread. To investigate how market conditions incrementally affect the premiums of deals involving financial bidders, we additionally include the credit spread (CREDIT_SPREAD) and the interaction of FIN_BIDDER and CREDIT_SPREAD (FIN_BIDDER*CREDIT_SPREAD) as variables in the regressions of the first and financial deal premiums.

Table 9 presents the estimation results of deal premiums after considering the market conditions in various years. The dependent variables of Models 1 and 2 are the first and final premiums, respectively. We note that a higher CREDIT_SPREAD value (representing a higher debt cost for the investor) leads to higher first premiums, rather 
than final premiums, that financial bidders will offer. The insignificant coefficients on the interactions in both models indicate that, consistently, the market conditions do not additionally influence the financial bidders' decisions on how much they are willing to pay for the targets. These results release our concern regarding the different performance level of financial bidders in different market conditions.

\section{Conclusion}

The current study is the first to examine the effects of making possible offers before formal bids on takeover gains, based on a natural-experiment design. Using UK takeovers, we find that in the years following the 'put-up or shut-up' (PUSU) reform, bidders, especially financial bidders, are less interested in disclosing possible takeover discussion before announcing formal takeovers. The stock market significantly and positively responds to possible-offer announcements, while the target shareholders of takeovers with possible offers generate lower abnormal returns through formal-offer announcements. Perhaps a possible offer signals to the market the higher probability of a formal bid being offered; thus, if a possible offer had already been earlier revealed, the market sustains less shock when a formal offer is published. Moreover, we find that the disclosure of potential takeover discussions leading to higher target price run-ups contributes positively to the bid premiums, which means that it adds to the bidders' bidding costs.

Our empirical results provide only weak evidence of the incremental contribution of financial bidders to the association between possible offers and shareholder returns around either possible offers or formal offers. However, the publication of possible bid interests helps target shareholders obtain significantly higher bid premiums; this effect is even more striking when a possible offer is made by a financial bidder. This means that while financial bidders have less of an interest in 
bidding with an initial possible offer, when they do, they will need to pay higher premiums to their targets. Furthermore, when considering whether the offer price that financial bidders pay for targets is influenced by macroeconomic conditions, our results allow us release this concern by presenting the insignificantly incremental effect of credit spread.

Finally, our results show that the reform inherent in the Takeover Code of 2011 greatly truncates the pending period from the possible-offer announcement date to the formal-offer announcement date. Nonetheless, the reform has no impact on the wealth gains of target firms. By separately examining the role of possible offers on the wealth effect of targets and comparing them before and after the year of reform, we find that the reform inherent in the Takeover Code imposes a time-variant structure break. In the pre-reform period, improved bid premiums caused by possible offers may explain the higher shareholder returns generated by formal takeover announcements. However, the Takeover Code reform and especially its 28-day PUSU clause triggers the negative effect that possible-offer announcements have on the wealth gains of targets through formal takeover announcements. 
Notes:

1. An anecdotal evidence hampered by the 28-day PUSU is the deal transaction between $\mathbf{J}$ Sainsbury plc (Sainsbury's), the second largest chain of supermarkets in the UK and Home Retail Group plc (HRG), a home and general merchandise retailer in the UK completed on 2 September 2016. Sainsbury's confirmed its earlier approach to HRG regarding a possible offer on 5 January 2016 and the detail of the consideration was given on 2 February 2016. Another competitor, Steinhoff International Holdings NV (Steinhoff) announced the terms of possible offer to HRG on 19 February 2016. Following this, both Sainsbury's and Steinhoff were requested to express an intention of making a formal offer by 18 March 2016. On 18 March 2016, Sainsbury's announced its intention to offer a formal bid for HRG, but Steinhoff chose to terminate the takeover discussion.

2. As it will be seen later in the paper, 90 takeovers with possible offers can find matching takeovers without possible offers when requesting the dates of formal offers of matching deals are the same. This process results in 180 takeovers.

3. Alexandridis, Fuller, Terhaar, and Travlos (2013) present the 3-day deal announcement returns of target firms using takeovers of public targets by private and public acquirers undertaken between 1990 and 2007. The target shareholder returns are 20.32 percent on average.

4. Mulherin and Simsir (2015) state that the SDC platinum does not record all 'Original Date Announced' (ODA) of US takeovers. According to their research, ODA is the date when '... the target company is first publicly disclosed as a possible takeover candidate.' It is the same date of what I mean in this paper by the date of possible deal announcement.

5. All variables are defined in Appendix A.

6. Our results of DiD regressions in Tables 6 and 7 are robust if we further request the matching needs to be within the specified radius given by caliper of 0.01 (unreported). 
7. The matching variables are consistent with those in Section 5.3.. The mean value of the percentage bias is less than five percentage.

8. The hazard function is referred to Giot and Schwienbacher's (2007) research, which exploits the possible exit options of venture capital-backed firms.

9. We notice that the F-statistics tests are insignificant for Models 2 and 3 in Panel B of Table 8. When excluding industry and year fixed-effect, the results of the F-statistics tests are significant. The effect of announcing possible offers are robust if with or without industry and year fixedeffect in the regressions of bid premiums. 


\section{Appendix A. Variable definitions}

\begin{tabular}{|c|c|}
\hline Variable & Definition \\
\hline POSSIBLE_OFFER & $\begin{array}{l}\text { Deals with possible offers. Binary variable for a takeover initiated by a possible } \\
\text { offer before formal bid offer announced by the same bidder. }\end{array}$ \\
\hline FIN_BIDDER & $\begin{array}{l}\text { Deals approached by financial bidders (with SIC code from } 6000 \text { to 6999). Binary } \\
\text { variable for a takeover approached by a financial bidder. }\end{array}$ \\
\hline POST_REFORM & $\begin{array}{l}\text { Post-reform period. Binary variable for a takeover announced after the reform of } \\
\text { the City Code in } 2011 \text { from the SDC Platinum database. }\end{array}$ \\
\hline TARGET_SIZE & $\begin{array}{l}\text { Target firm size. Market value of equity minus book value of equity plus book } \\
\text { value of total assets in nominal terms. For the reporting period end before the } \\
\text { (latent) acquisition announcement year from the Datastream database. In million } \\
\text { dollar units and real (2016) terms. }\end{array}$ \\
\hline AGE & $\begin{array}{l}\text { Firm age. (Latent) acquisition announcement year minus base year in the } \\
\text { Datastream database (minimum 1964) plus one. }\end{array}$ \\
\hline SALE_GROWTH & $\begin{array}{l}\text { Growth rate of sales. Average growth rate of sales for a maximum of three and a } \\
\text { minimum of two reporting period ends before the (latent) acquisition } \\
\text { announcement year from the Datastream database. Sales are annualized and in real } \\
\text { (2016) terms. }\end{array}$ \\
\hline
\end{tabular}

Q_RATIO

LIQUIDITY

Market to book ratio. Firm size in market value divided by from size in book value. For the reporting period end before the (latent) acquisition announcement year from the Datastream database.

Liquidity ratio. Cash and marketable securities divided by firm size in book value in nominal terms. For the reporting period end before the (latent) acquisition announcement year from the Datastream database.

LEVERAGE

Leverage ratio. Book value of total debt divided by firm size in book value in nominal terms. For the reporting period end before the (latent) acquisition announcement year from the Datastream database.

TANGIBILITY Tangibility ratio. Book value of property, plant, and equipment (PPE) divided by firm size in book value in nominal terms. For the reporting period end before the (latent) acquisition announcement year from the Datastream database.

ROA

ROA_SD

Return on assets. Operating incomes plus depreciation (annualized) divided by firm size in book value in nominal terms. For the reporting period end before the (latent) acquisition announcement year from the Datastream database.

Volatility of return on assets. Standard deviation of ROA for a maximum of three and a minimum of two reporting period ends before the (latent) acquisition announcement year.

HHI

Herfindahl index. Industry listed firm concentration. Herfindahl index for the shares of sales (annualized and in decimal units) for the Industry Classification Benchmark industry. For the reporting period end before the (latent) acquisition announcement year from the Datastream database.

THREATS_TAKEOVER Takeover intensity peak. Binary variable for takeover intensity at least one standard deviation above the average takeover intensity. Takeover intensity is calculated by aggregate transaction value of takeovers in nominal term divided by aggregate value of listed firms in book value in nominal term for reporting period ends in the (latent) acquisition announcement year.

TOEHOLD

Percentage of shareholdings that the offeror owns in the target firm prior to the takeover announcement. 
CASH_DEAL

SHARE_DEAL

PUB_PUB

PRI_PUB

DOMESTIC

HOSTILE

IND_MATCH

CREDIT_SPREAD

FIRST_PREMIUM

FINAL_PREMIUM

CAR_3DAY

CAR_5DAY
Cash deal. Binary variable for a takeover paid for all in cash from the SDC Platinum database.

Stock deal. Binary variable for a takeover paid for all in stock from the SDC Platinum database.

Public deal. Binary variable for a takeover offered by a public firm from the SDC Platinum database.

Private deal. Binary variable for a takeover offered by a private firm from the SDC Platinum database.

Domestic deal. Binary variable for a takeover offered by a firm from the same country as the target from the SDC Platinum database.

Hostile deal. Binary variable for a hostile acquisition from the SDC Platinum database.

Industry match. Binary variables for a takeover offered by a firm from the industry with the same two-digit SIC code.

Aggregate economic condition. The difference between the average 10-year yield of UK Benchmark AAA bonds in the last year of the deal announcement and the average 10-year UK Government Stored yield in the same period.

First offer premium. The difference between the first offer price to each share of the target and the target share price 41 day prior to the identified offer announcement date divided by the target share price 41 days prior to the identified offer date.

Final offer premium. The difference between the final offer price to each share of the target and the target share price 41 day prior to the identified offer announcement date divided by the target share price 41 days prior to the identified offer date.

3-day cumulative abnormal returns (CARs). 3-day CARs around the identified offer announcement date. Abnormal returns are calculated based on the market model. The estimation window is over the period of 242 to 42 trading days prior to the identified takeover announcement date.

5-day cumulative abnormal returns (CARs). 5-day CARs around the identified offer announcement date. Abnormal returns are calculated based on the market model. The estimation window is over the period of 242 to 42 trading days prior to the identified takeover announcement date. 


\section{Appendix B. A case of takeover with possible offer announcement}

In the final document of the recommended cash offer for European Motor Holdings (EMH) plc by Inchcape plc, it records the full history of the negotiation process of the deal. On page 9, it states '... on 4 December 2006, the day before EMH confirms that it was in discussions with interested parties in relation to a possible offer for EMH.'

When tracking the record of this takeover, on $5^{\text {th }}$ December, 2006, there was a document acknowledging the announcement of possible offer from EMH. '...EMH notes the recent press speculation and confirms that it is in discussions with interested parties in relation to a possible offer for EMH.' 


\section{Figures}

\section{Figure 1 Negotiation process of UK takeovers}

This figure presents the whole negotiation process of a takeover in the UK. Before the date of possible offer announcement, it is defined as private negotiation. The period between the dates of recognized rumor and possible offer announcement is defined as pre-public negotiation. The period from the date of announcing formal offer until the resolution of the deal is defined as public negotiation.

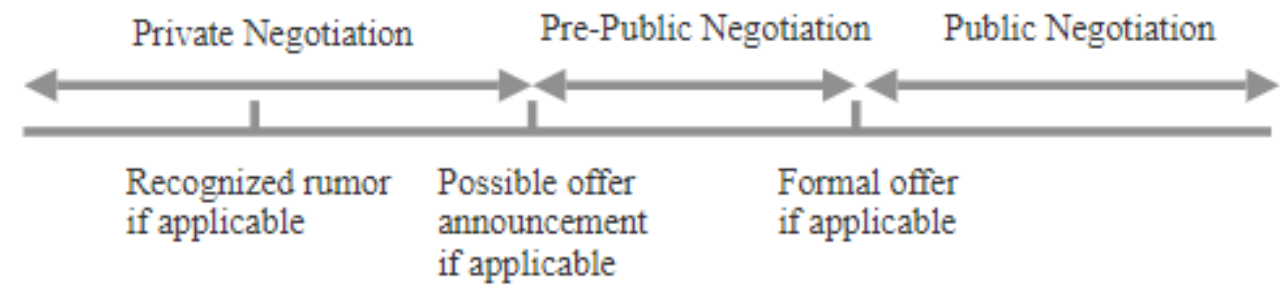


Figure 2 Survival Analysis: The effect of 28-day PUSU in the updated Takeover Code

This figure plots the hazard failure rate estimated by the Kaplan-Meier hazard function using takeovers undertaken in pre- and post- reform. Figure $2 \mathrm{a}$ plots the risk of being formally taken over at days after the possible offer announcement in the pre-reform period. Figure $2 b$ plots the risk of being formally taken over at days after the possible offer announcement in the post-reform period.

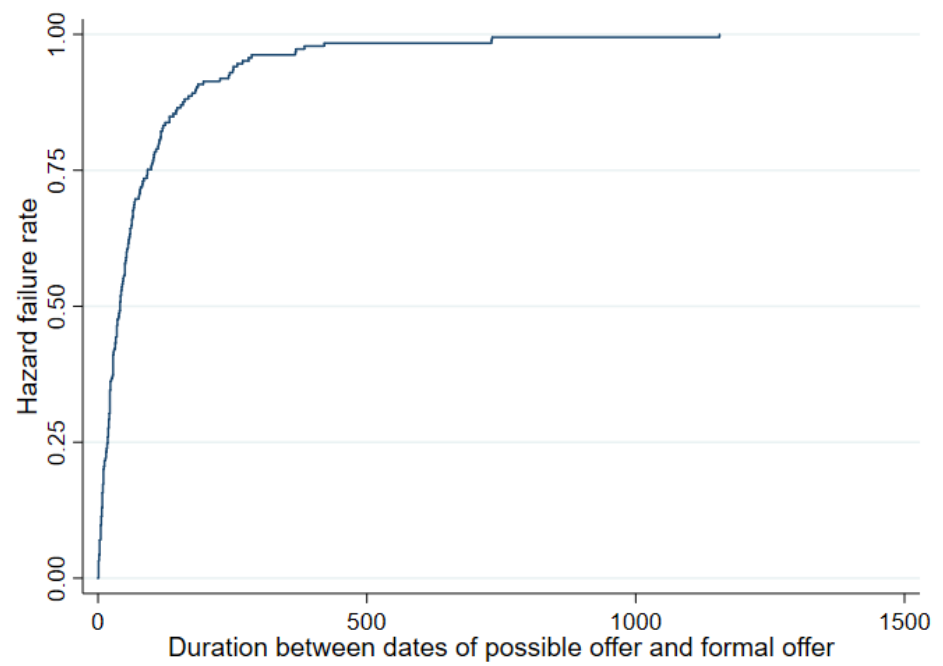

Figure $2 a$ Pre-reform hazard rate function

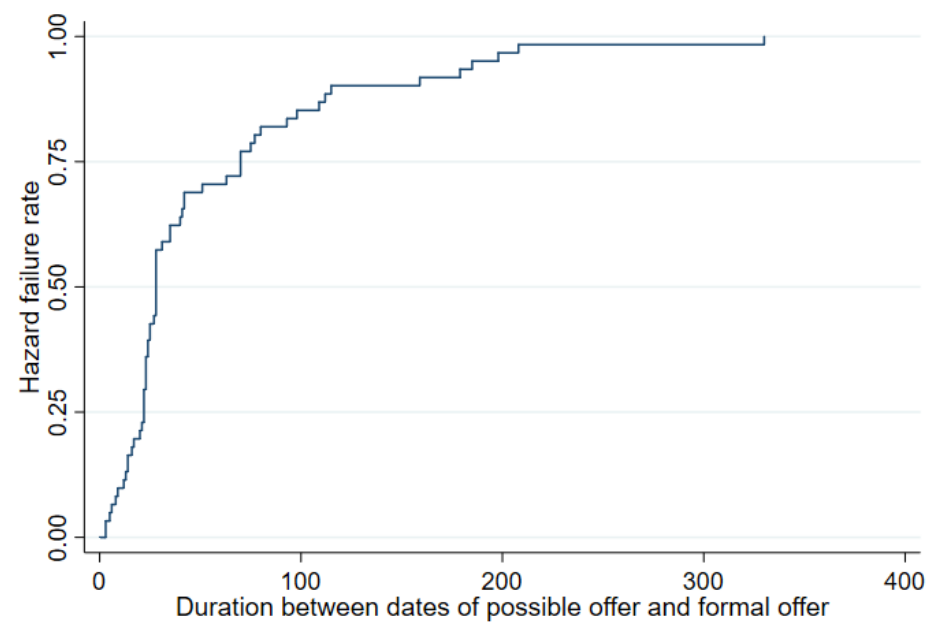

Figure $2 b$ Post-reform hazard rate function 


\section{Tables}

Table 1 Distribution of takeovers by years

This table presents the distribution of takeovers by years from 2006 to 2016 . It also presents the distribution of two sub-samples of takeovers: with possible offer and without possible offer. The final column is possible offer intensity in each year. Intensity of possible offer is calculated by the number of takeovers with possible offer being scaled by the total number of takeovers in corresponding year.

\begin{tabular}{|c|c|c|c|c|}
\hline Year & No. of Takeovers & With Possible Offer & Without Possible Offer & Intensity of Possible Offer \\
\hline 2006 & 140 & 18 & 122 & 0.1286 \\
\hline 2007 & 129 & 72 & 57 & 0.5581 \\
\hline 2008 & 145 & 84 & 61 & 0.5793 \\
\hline 2009 & 93 & 48 & 45 & 0.5161 \\
\hline 2010 & 99 & 42 & 57 & 0.4242 \\
\hline 2011 & 80 & 34 & 46 & 0.4250 \\
\hline 2012 & 68 & 20 & 48 & 0.2941 \\
\hline 2013 & 41 & 17 & 24 & 0.4146 \\
\hline 2014 & 62 & 24 & 38 & 0.3871 \\
\hline 2015 & 63 & 31 & 32 & 0.4921 \\
\hline 2016 & 70 & 19 & 51 & 0.2714 \\
\hline Total & 990 & 409 & 581 & 0.4131 \\
\hline
\end{tabular}


Table 2 Descriptive statistics of wealth gains of target shareholders

This table presents descriptive statistics for possible deal announcement returns, formal deal announcement returns and bid premiums. Panel A presents the 3 day cumulative abnormal returns (CARs) over the window $[-1,+1]$, where day 0 is the possible-offer announcement date. 409 out of 990 takeovers have possible offer announcement before formal one. By matching formal deal announcement dates of takeovers with and without possible offers, 90 takeovers with possible offers successfully find corresponding takeovers without possible offers. Panel B presents the descriptive statistics of wealth gains of target's shareholders represented by price runup in the period leading up to a formal offer, deal announcement returns of formal offers and bid premiums. 3-day (5-day) CARs are CARs around the identified offer announcement date over the window $[-1,+1]([-2,+2])$. Abnormal returns are calculated based on the market model. The estimation window is over the period of 242 to 42 trading days prior to the formal takeover announcement date. The first (final) premium is calculated by the difference between the first (final) offer price to each share of the target and the target share price 41 day prior to the identified offer announcement date being divided by the target share price 41 days prior to the formal offer date. Where there is no updated price, final price is equal to first price. This table also presents the value of CARs and premiums of two sub-samples: takeovers with and without possible offers. The significance of the differences of mean (median) values

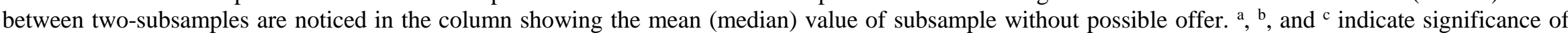
mean (median) differences between takeovers with and without possible offer at the one, five and ten percent level respectively.

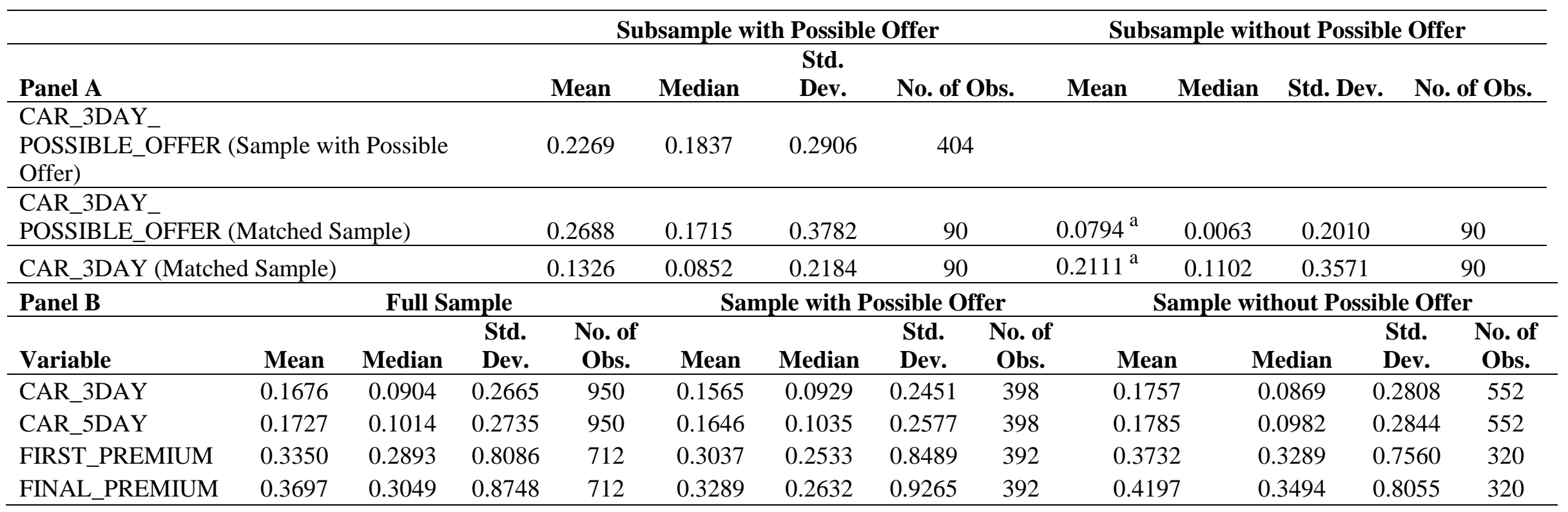


Table 3 Descriptive statistics of all variables

This table presents descriptive statistics of all variables for full sample, subsample with possible offer, and subsample without possible offer. Variables are defined in Appendix. The significance of the differences of mean (median) value between two subsamples are noticed in the column showing the mean (median) value of subsample without possible offer. ${ }^{a},{ }^{b}$, and ${ }^{c}$ indicate the significance of mean (median) differences between takeovers with and without possible offer at the one, five and ten percent level respectively.

\begin{tabular}{|c|c|c|c|c|c|c|c|c|c|c|c|c|}
\hline \multirow[b]{2}{*}{ Variable } & \multicolumn{4}{|c|}{ Full Sample } & \multicolumn{4}{|c|}{ Subsample with Possible Offer } & \multicolumn{4}{|c|}{ Subsample without Possible Offer } \\
\hline & Mean & Median & Std. Dev. & $\begin{array}{c}\text { No. of } \\
\text { Obs. }\end{array}$ & Mean & Median & Std. Dev. & $\begin{array}{l}\text { No. of } \\
\text { Obs. }\end{array}$ & Mean & Median & Std. Dev. & $\begin{array}{c}\text { No. of } \\
\text { Obs. }\end{array}$ \\
\hline FIN_BIDDER & 0.4303 & 0.0000 & 0.4954 & 990 & 0.3961 & 0.0000 & 0.4897 & 409 & $0.4544^{\mathrm{c}}$ & $0.0000^{\mathrm{c}}$ & 0.4983 & 581 \\
\hline POST_REFORM & 0.3071 & 0.0000 & 0.4615 & 990 & 0.2714 & 0.0000 & 0.4452 & 409 & $0.3322^{b}$ & $0.0000^{\mathrm{b}}$ & 0.4714 & 581 \\
\hline TARGET_SIZE & 7375.65 & 371.22 & 40926.07 & 877 & 4526.38 & 437.66 & 18769.39 & 375 & 9504.09 & 310.99 & 51527.09 & 502 \\
\hline AGE & 14.8271 & 10.0000 & 13.1641 & 989 & 14.6235 & 10.0000 & 12.9484 & 409 & 14.9707 & 10.0000 & 13.3233 & 580 \\
\hline SALE_ & & & & & & & & & & & & \\
\hline GROWTTH & 0.5271 & 0.0884 & 2.0127 & 867 & 0.4486 & 0.1117 & 1.4137 & 367 & 0.5847 & $0.0787^{\mathrm{c}}$ & 2.3573 & 500 \\
\hline LEVERAGE & 0.1895 & 0.1491 & 0.1900 & 889 & 0.1887 & 0.1563 & 0.1816 & 379 & 0.1901 & 0.1433 & 0.1962 & 510 \\
\hline LIQUIDITY & 0.1675 & 0.0971 & 0.1900 & 891 & 0.1499 & 0.0856 & 0.1670 & 379 & $0.1805^{b}$ & $0.1102^{b}$ & 0.2046 & 512 \\
\hline Q_RATIO & 2.1396 & 1.7756 & 1.2310 & 877 & 2.0805 & 1.7488 & 1.1252 & 375 & 2.1838 & 1.8040 & 1.3038 & 502 \\
\hline ROA & 0.0108 & 0.0768 & 0.2787 & 878 & 0.0309 & 0.0835 & 0.2433 & 374 & $-0.0040^{\mathrm{c}}$ & $0.0676^{c}$ & 0.3016 & 504 \\
\hline ROA_SD & 0.1133 & 0.0544 & 0.1903 & 905 & 0.0971 & 0.0506 & 0.1632 & 380 & $0.1251^{b}$ & 0.0588 & 0.2071 & 525 \\
\hline TANGIBILITY & 0.2462 & 0.1292 & 0.2657 & 885 & 0.2491 & 0.1406 & 0.2615 & 378 & 0.2440 & 0.1228 & 0.2690 & 507 \\
\hline HHI & 0.4519 & 0.3730 & 0.2920 & 990 & 0.4569 & 0.3880 & 0.2953 & 409 & 0.4484 & 0.3730 & 0.2899 & 581 \\
\hline TAKEOVER_ & & & & & & & & & & & & \\
\hline THREAT & 0.3273 & 0.0000 & 0.4695 & 990 & 0.3570 & 0.0000 & 0.4797 & 409 & 0.3064 & 0.0000 & 0.4614 & 581 \\
\hline TOEHOLD & 4.3450 & 0.0000 & 11.1452 & 990 & 3.7570 & 0.0000 & 9.9563 & 409 & 4.7588 & 0.0000 & 11.9022 & 581 \\
\hline CASH_DEAL & 0.5111 & 1.0000 & 0.5001 & 990 & 0.5403 & 1.0000 & 0.4990 & 409 & 0.4905 & 0.0000 & 0.5003 & 581 \\
\hline SHARE_DEAL & 0.1051 & 0.0000 & 0.3068 & 990 & 0.1296 & 0.0000 & 0.3363 & 409 & $0.0878^{b}$ & 0.0000 & 0.2832 & 581 \\
\hline PUB_PUB & 0.4172 & 0.0000 & 0.4933 & 990 & 0.4719 & 0.0000 & 0.4998 & 409 & $0.3787^{\mathrm{a}}$ & 0.0000 & 0.4855 & 581 \\
\hline PRIV_PUB & 0.2899 & 0.0000 & 0.4539 & 990 & 0.2543 & 0.0000 & 0.4360 & 409 & $0.3150^{\mathrm{b}}$ & 0.0000 & 0.4649 & 581 \\
\hline DOMESTIC & 0.4889 & 0.0000 & 0.5001 & 990 & 0.5012 & 1.0000 & 0.5006 & 409 & 0.4802 & 0.0000 & 0.5000 & 581 \\
\hline HOSTILE & 0.0242 & 0.0000 & 0.1539 & 990 & 0.0269 & 0.0000 & 0.1620 & 409 & 0.0224 & 0.0000 & 0.1480 & 581 \\
\hline IND_MATCH & 0.3818 & 0.0000 & 0.4861 & 990 & 0.3936 & 0.0000 & 0.4892 & 409 & 0.3735 & 0.0000 & 0.4841 & 581 \\
\hline
\end{tabular}


Table 4 The determinants of possible-offer announcement

This table presents the probit model results of the determinants of announcing possible offer conditional on having formal takeover announcement. The dependent variable is a binary variable, which equals 1 if possible offer is identified before formal offer; 0 otherwise. Independent variables are defined in Appendix. Industry fixed-effect is controlled. Standard errors are adjusted for heteroscedasticity. ${ }^{\mathrm{a}},{ }^{\mathrm{b}}$, and ${ }^{\mathrm{c}}$ indicate the significance of coefficients and Wald statistics at the one, five and ten percent levels respectively.

\begin{tabular}{|c|c|c|}
\hline Possible Offer & Marginal Effect & Std. Error \\
\hline FIN_BIDDER & $-0.0851^{b}$ & 0.0352 \\
\hline POST_REFORM & $-0.1214^{\mathrm{a}}$ & 0.0420 \\
\hline LN(TARGET_SIZE) & 0.0100 & 0.0099 \\
\hline AGE & $-0.0024^{\mathrm{c}}$ & 0.0014 \\
\hline SALE_GROWTH & -0.0110 & 0.0086 \\
\hline Q_RATIO & $-0.0321^{\mathrm{c}}$ & 0.0189 \\
\hline LIQUIDITY & -0.0209 & 0.1231 \\
\hline LEVERAGE & -0.0778 & 0.1051 \\
\hline TANGIBILITY & 0.0790 & 0.0734 \\
\hline ROA_SD & -0.0729 & 0.1157 \\
\hline HHI & 0.0651 & 0.0702 \\
\hline TAKEOVER_THREAT & $0.1372^{\mathrm{a}}$ & 0.0414 \\
\hline CONSTANT & $0.4324^{\mathrm{c}}$ & 0.0171 \\
\hline Industry fixed-effect & Yes & \\
\hline Year fixed-effect & No & \\
\hline Wald $\mathrm{Chi}^{2}$ & $39.17^{\mathrm{a}}$ & \\
\hline P-value of Wald test & 0.004 & \\
\hline Pseudo $\mathrm{R}^{2}$ & 0.038 & \\
\hline No. of Obs. & 800 & \\
\hline
\end{tabular}


Table 5 The regressions of deal announcement returns around possible-offer announcement

This table presents the regression estimates for the effects of possible offer and financial bidders on possible offer announcement returns using matched sample takeovers (same formal offer date; with and without possible offer). The dependent variable is 3-day CARs around the possible deal announcement. Model 1 presents the estimating results of the effects of possible offer and financial bidder on the CARs, individually. Model 2 presents the DiD regression results of the incremental effect of financial bidders on the association of possible offer and CARs. All variables are defined in Appendix. Industry and year fixed-effect are controlled. Standard errors are adjusted for heteroscedasticity. ${ }^{a},{ }^{b}$, and ${ }^{c}$ indicate the significance of coefficients and F statistics at the one, five and ten percent level respectively.

\begin{tabular}{|c|c|c|c|c|}
\hline \multirow[b]{2}{*}{ CARs } & \multicolumn{2}{|c|}{ Model 1} & \multicolumn{2}{|c|}{ Model 2} \\
\hline & Coefficient & Std. Error & Coefficient & Std. Error \\
\hline POSSIBLE_OFFER & $0.1507^{\mathrm{a}}$ & 0.0370 & $0.0901^{\mathrm{c}}$ & 0.0507 \\
\hline FIN_BIDDER & -0.0064 & 0.0566 & -0.0533 & 0.0693 \\
\hline $\begin{array}{l}\text { POSSIBLE_OFFER* } \\
\text { FIN_BIDDER }\end{array}$ & & & $0.1256^{\mathrm{c}}$ & 0.0744 \\
\hline POST_REFORM & -0.0107 & 0.0988 & -0.0523 & 0.1093 \\
\hline LN(TARGET_SIZE) & -0.0072 & 0.0112 & -0.0072 & 0.0109 \\
\hline LEVERAGE & -0.0107 & 0.0988 & -0.1221 & 0.1141 \\
\hline ROA & $-0.1219^{c}$ & 0.0670 & $-0.1423^{b}$ & 0.0685 \\
\hline Q_RATIO & $-0.0413^{\mathrm{c}}$ & 0.0245 & -0.0369 & 0.0242 \\
\hline HHI & 0.0838 & 0.0821 & 0.0899 & 0.0813 \\
\hline TOEHOLD & $-0.0046^{\mathrm{a}}$ & 0.0014 & $-0.0042^{\mathrm{a}}$ & 0.0014 \\
\hline CASH_DEAL & $0.1093^{b}$ & 0.0503 & $0.1189^{\mathrm{b}}$ & 0.0486 \\
\hline SHARE_DEAL & -0.0595 & 0.0541 & -0.0275 & 0.0557 \\
\hline PUB_PUB & -0.0427 & 0.0588 & -0.0271 & 0.0575 \\
\hline PRIV_PUB & -0.0845 & 0.0572 & -0.0782 & 0.0552 \\
\hline DOMESTIC & 0.0011 & 0.0412 & -0.0003 & 0.0384 \\
\hline HOSTILE & 0.0791 & 0.0861 & 0.0744 & 0.0780 \\
\hline IND_MATCH & -0.0763 & 0.0516 & -0.0703 & 0.0495 \\
\hline CONSTANT & 0.1207 & 0.1656 & 0.1382 & 0.1627 \\
\hline Industry fixed-effect & Yes & & Yes & \\
\hline Year fixed-effect & Yes & & Yes & \\
\hline F-statistics & $6.03^{\mathrm{a}}$ & & $5.11^{\mathrm{a}}$ & \\
\hline P-value of F-statistics & 0.000 & & 0.000 & \\
\hline $\mathrm{R}^{2}$ & 0.354 & & 0.371 & \\
\hline No. of Obs. & 156 & & 156 & \\
\hline
\end{tabular}


Table 6 The regressions of deal announcement returns around formal-offer announcement

This table presents the regression estimates for the effects of possible offer and financial bidders on formal offer announcement returns using full sample. The dependent variable is 3-day CARs around the deal announcement. Model 1 presents the results of the effects of possible offer and financial bidder on the CARs, individually. Model 2 presents the $\mathrm{DiD}$ regression results of the incremental effect of financial bidders on the association of possible offer and CARs based on the matched sample using PSM method. All variables are defined in Appendix. Industry and year fixed-effect are controlled. Standard errors are adjusted for heteroscedasticity. ${ }^{\mathrm{a}}, \mathrm{b},{ }^{\mathrm{c}}$ indicate the significance of coefficients and F statistics at the one, five and ten percent level respectively.

\begin{tabular}{|c|c|c|c|c|}
\hline \multirow[b]{2}{*}{ CARs } & \multicolumn{2}{|c|}{ Model 1} & \multicolumn{2}{|c|}{ Model 2} \\
\hline & Coefficient & Std. Error & Coefficient & Std. Error \\
\hline POSSIBLE_OFFER & $-0.0392^{b}$ & 0.0196 & $-0.0573^{b}$ & 0.0250 \\
\hline FIN_BIDDER & -0.0241 & 0.0309 & 0.0323 & 0.0501 \\
\hline $\begin{array}{l}\text { POSSIBLE_OFFER* } \\
\text { FIN_BIDDER }\end{array}$ & & & -0.0428 & 0.0460 \\
\hline POST_REFORM & 0.0190 & 0.0444 & -0.0436 & 0.1063 \\
\hline LN(TARGET_SIZE) & $-0.0105^{c}$ & 0.0056 & $-0.0114^{\mathrm{c}}$ & 0.0063 \\
\hline LEVERAGE & -0.0454 & 0.0592 & -0.0571 & 0.0591 \\
\hline ROA & 0.0325 & 0.0553 & -0.0056 & 0.0546 \\
\hline Q_RATIO & -0.0102 & 0.0071 & $-0.0195^{\mathrm{a}}$ & 0.0072 \\
\hline HHI & -0.0649 & 0.0459 & -0.0632 & 0.0434 \\
\hline TOEHOLD & $-0.0019^{b}$ & 0.0008 & $-0.0030^{\mathrm{a}}$ & 0.0008 \\
\hline CASH_DEAL & $0.1360^{\mathrm{a}}$ & 0.0233 & $0.1539^{\mathrm{a}}$ & 0.0235 \\
\hline SHARE_DEAL & -0.0132 & 0.0255 & 0.0033 & 0.0283 \\
\hline PUB_PUB & -0.0472 & 0.0316 & -0.0491 & 0.0344 \\
\hline PRIV_PUB & $-0.0805^{\mathrm{a}}$ & 0.0296 & $-0.1165^{\mathrm{a}}$ & 0.0369 \\
\hline DOMESTIC & -0.0267 & 0.0213 & -0.0104 & 0.0265 \\
\hline HOSTILE & 0.0196 & 0.0480 & 0.0592 & 0.0505 \\
\hline IND_MATCH & -0.0122 & 0.0246 & $-0.0454^{\mathrm{c}}$ & 0.0258 \\
\hline CONSTANT & $0.3425^{\mathrm{a}}$ & 0.0781 & $0.5161^{\mathrm{a}}$ & 0.1355 \\
\hline Industry fixed-effect & Yes & & Yes & \\
\hline Year fixed-effect & Yes & & Yes & \\
\hline F-statistics & $5.75^{\mathrm{a}}$ & & $5.74^{\mathrm{a}}$ & \\
\hline P-value of F-statistics & 0.000 & & 0.000 & \\
\hline $\mathrm{R}^{2}$ & 0.166 & & 0.213 & \\
\hline No. of Obs. & 831 & & 721 & \\
\hline
\end{tabular}


Table 7 The regressions of first and final bid premiums

This table presents the regression estimates the effects of possible offer and financial bidders on bid premiums using full sample. The dependent variable is the first premiums in Panel A and is the final premiums in Panel B. Model 1 of Panel A (Panel B) presents the estimating results of the effects of possible offer and financial bidder on the first (final) premiums. Model 2 of Panel A (Panel B) presents the DiD regression results of the incremental effect of financial bidders on the association of possible offer and first (final) premiums based on the matched sample using PSM method. All variables are defined in Appendix. Industry and year fixed-effect are controlled. Standard errors are adjusted for heteroscedasticity. a , b, c indicate the significance of coefficients and F statistics at the one, five and ten percent level respectively.

\begin{tabular}{|c|c|c|c|c|}
\hline \multirow[b]{2}{*}{ Panel A First Premiums } & \multicolumn{2}{|c|}{ Model 1} & \multicolumn{2}{|c|}{ Model 2} \\
\hline & Coefficient & Std. Error & Coefficient & Std. Error \\
\hline POSSIBLE_OFFER & $0.1895^{\mathrm{c}}$ & 0.1005 & 0.0716 & 0.1045 \\
\hline FIN_BIDDER & -0.0207 & 0.1032 & $-0.7524^{\mathrm{a}}$ & 0.2356 \\
\hline $\begin{array}{l}\text { POSSIBLE_OFFER* } \\
\text { FIN_BIDDER }\end{array}$ & & & $0.6810^{\mathrm{a}}$ & 0.2615 \\
\hline POST_REFORM & 0.2214 & 0.1377 & $0.5406^{\mathrm{b}}$ & 0.2610 \\
\hline LN(TARGET_SIZE) & -0.0128 & 0.0322 & $-0.0964^{\mathrm{a}}$ & 0.0362 \\
\hline LEVERAGE & 0.0330 & 0.2491 & 0.3090 & 0.3550 \\
\hline Q_RATIO & -0.0269 & 0.0379 & -0.0589 & 0.0500 \\
\hline TOEHOLD & $-0.0102^{c}$ & 0.0061 & $-0.0294^{\mathrm{a}}$ & 0.0091 \\
\hline DOMESTIC & $0.2037^{b}$ & 0.0948 & $0.2530^{b}$ & 0.1001 \\
\hline SHARE_DEAL & $-0.2714^{\mathrm{c}}$ & 0.1524 & $-0.4621^{\mathrm{a}}$ & 0.1757 \\
\hline PRIV_PUB & $-0.2705^{\mathrm{c}}$ & 0.1445 & $-0.2905^{\mathrm{c}}$ & 0.1687 \\
\hline HOSTILE & -0.3860 & 0.3657 & $-1.1839^{\mathrm{a}}$ & 0.3771 \\
\hline CONSTANT & -0.1772 & 0.3909 & 0.4814 & 0.4272 \\
\hline Industry fixed-effect & Yes & & Yes & \\
\hline Year fixed-effect & Yes & & Yes & \\
\hline F-statistics & $1.50^{\mathrm{b}}$ & & $3.19^{\mathrm{a}}$ & \\
\hline P-value of F-statistics & 0.050 & & 0.000 & \\
\hline $\mathrm{R}^{2}$ & 0.08 & & 0.26 & \\
\hline \multirow[t]{2}{*}{ No. of Obs. } & 641 & & 592 & \\
\hline & \multicolumn{2}{|c|}{ Model 1} & \multicolumn{2}{|c|}{ Model 2} \\
\hline Panel B Final Premiums & Coefficient & Std. Error & Coefficient & Std. Error \\
\hline POSSIBLE_OFFER & $0.1951^{b}$ & 0.0989 & 0.1320 & 0.1041 \\
\hline FIN_BIDDER & 0.0252 & 0.0996 & $-0.5249^{b}$ & 0.2141 \\
\hline $\begin{array}{l}\text { POSSIBLE_OFFER* } \\
\text { FIN_BIDDER }\end{array}$ & & & $0.5035^{\mathrm{b}}$ & 0.2410 \\
\hline POST_REFORM & 0.2049 & 0.1356 & $0.5287^{b}$ & 0.2487 \\
\hline LN(TARGET_SIZE) & 0.0095 & 0.0307 & $-0.0686^{\mathrm{c}}$ & 0.0352 \\
\hline LEVERAGE & -0.0102 & 0.2498 & 0.2236 & 0.3516 \\
\hline Q_RATIO & -0.0334 & 0.0383 & -0.0740 & 0.0536 \\
\hline TOEHOLD & $-0.0116^{\mathrm{c}}$ & 0.0061 & $-0.0312^{\mathrm{a}}$ & 0.0091 \\
\hline
\end{tabular}


Table 7 (Cont'd)

\begin{tabular}{|c|c|c|c|c|}
\hline DOMESTIC & $0.2047^{\mathrm{b}}$ & 0.0926 & $0.2350^{\mathrm{b}}$ & 0.0967 \\
\hline SHARE_DEAL & $-0.2479^{c}$ & 0.1502 & $-0.4424^{b}$ & 0.1783 \\
\hline PRIV_PUB & $-0.2669^{c}$ & 0.1427 & $-0.2892^{c}$ & 0.1656 \\
\hline HOSTILE & -0.1614 & 0.3291 & $-1.0531^{\mathrm{a}}$ & 0.3709 \\
\hline CONSTANT & -0.2363 & 0.3845 & 0.5993 & 0.4143 \\
\hline Industry fixed-effect & Yes & & Yes & \\
\hline Year fixed-effect & Yes & & Yes & \\
\hline F-statistics & $1.52^{\mathrm{b}}$ & & $2.88^{\mathrm{a}}$ & \\
\hline P-value of F-statistics & 0.047 & & 0.000 & \\
\hline $\mathrm{R}^{2}$ & 0.074 & & 0.252 & \\
\hline No. of Obs. & 641 & & 592 & \\
\hline
\end{tabular}


Table 8 The effects of possible-offer announcement in the pre-reform and post-reform periods

This table presents the regression estimates for the effect of announcing possible offer on deal announcement returns and premiums of takeovers undertaken before and after the year of the reform. From Model 1 to 3, the dependent variables are 3-day CARs around the deal announcement, first bid premiums, and final bid premiums, respectively. Panel A presents the estimation results in the pre-reform period. Panel B presents the estimation results in the post-reform period. All variables are defined in Appendix. Industry and year fixed-effect are controlled. Standard errors are adjusted for heteroscedasticity. ${ }^{\text {a }},{ }^{\mathrm{b}},{ }^{\mathrm{c}}$ indicate the significance of coefficients and F statistics at the one, five and ten percent level respectively.

\begin{tabular}{|c|c|c|c|c|c|c|}
\hline \multirow{2}{*}{$\begin{array}{l}\text { Panel A } \\
\text { Pre-reform }\end{array}$} & \multicolumn{2}{|c|}{ Model 1} & \multicolumn{2}{|c|}{ Model 2} & \multicolumn{2}{|c|}{ Model 3} \\
\hline & Coefficient & Std. Error & Coefficient & Std. Error & Coefficient & Std. Error \\
\hline POSSIBLE_OFFER & -0.0378 & 0.0235 & $0.2671^{\mathrm{b}}$ & 0.1343 & $0.2852^{b}$ & 0.1351 \\
\hline FIN_BIDDER & -0.0149 & 0.0349 & -0.0713 & 0.1345 & -0.0768 & 0.1340 \\
\hline LN(TARGET_SIZE) & -0.0077 & 0.0062 & 0.0115 & 0.0481 & 0.0486 & 0.0494 \\
\hline LEVERAGE & -0.0505 & 0.0724 & 0.1007 & 0.2938 & 0.0507 & 0.2945 \\
\hline $\mathrm{ROA}$ & 0.0116 & 0.0625 & & & & \\
\hline Q_RATIO & $-0.0191^{b}$ & 0.0086 & -0.0550 & 0.0578 & -0.0605 & 0.0590 \\
\hline $\mathrm{HHI}$ & $-0.1129^{c}$ & 0.0646 & & & & \\
\hline TOEHOLD & $-0.0016^{\mathrm{c}}$ & 0.0010 & -0.0114 & 0.0087 & -0.0124 & 0.0086 \\
\hline CASH_DEAL & $0.1283^{\mathrm{a}}$ & 0.0278 & & & & \\
\hline SHARE_DEAL & 0.0158 & 0.0330 & -0.3220 & 0.1998 & -0.2529 & 0.1903 \\
\hline PUB_PUB & $-0.0682^{c}$ & 0.0388 & & & & \\
\hline PRIV_PUB & $-0.1028^{\mathrm{a}}$ & 0.0357 & $-0.4304^{b}$ & 0.1931 & $-0.3521^{\mathrm{c}}$ & 0.1971 \\
\hline DOMESTIC & -0.0305 & 0.0272 & 0.2048 & 0.1252 & 0.2020 & 0.1238 \\
\hline HOSTILE & -0.0321 & 0.0504 & -0.7261 & 0.5070 & -0.4083 & 0.4403 \\
\hline IND_MATCH & -0.0224 & 0.0307 & & & & \\
\hline AUCTION & & & & & $-0.3290^{c}$ & 0.1909 \\
\hline CONSTANT & $0.3760^{\mathrm{a}}$ & 0.1020 & -0.0323 & 0.5418 & -0.2170 & 0.5465 \\
\hline Industry fixed-effect & Yes & & Yes & & Yes & \\
\hline
\end{tabular}


Table 8 (Cont'd)

\begin{tabular}{|c|c|c|c|c|c|c|}
\hline Year fixed-effect & Yes & & Yes & \multicolumn{3}{|c|}{ Yes } \\
\hline F-statistics & $4.06^{\mathrm{a}}$ & & $1.44^{\mathrm{c}}$ & \multicolumn{3}{|c|}{$1.48^{\mathrm{c}}$} \\
\hline P-value of F-statistics & 0.00 & & 0.09 & \multicolumn{3}{|c|}{0.07} \\
\hline $\mathrm{R}^{2}$ & 0.1635 & & 0.0953 & \multicolumn{3}{|c|}{0.1014} \\
\hline No. of Obs. & 568 & & 425 & \multicolumn{3}{|c|}{425} \\
\hline Panel B & \multicolumn{2}{|c|}{ Model 1} & \multicolumn{2}{|c|}{ Model 2} & \multicolumn{2}{|c|}{ Model 3} \\
\hline Post-reform & Coefficient & Std. Error & Coefficient & Std. Error & Coefficient & Std. Error \\
\hline POSSIBLE_OFFER & $-0.0622^{c}$ & 0.0359 & -0.0219 & 0.1832 & -0.0487 & 0.1793 \\
\hline FIN_BIDDER & -0.0547 & 0.0682 & 0.0881 & 0.1750 & $0.2472^{\mathrm{c}}$ & 0.1437 \\
\hline LN(TARGET_SIZE) & -0.0168 & 0.0119 & -0.0135 & 0.0381 & 0.0077 & 0.0367 \\
\hline LEVERAGE & -0.0132 & 0.1031 & -0.1939 & 0.3804 & -0.0980 & 0.3700 \\
\hline ROA & 0.1217 & 0.1076 & & & & \\
\hline Q_RATIO & 0.0128 & 0.0143 & 0.0489 & 0.0424 & 0.0343 & 0.0418 \\
\hline HHI & 0.0958 & 0.0853 & & & & \\
\hline TOEHOLD & $-0.0024^{\mathrm{c}}$ & 0.0013 & -0.0107 & 0.0079 & $-0.0136^{\mathrm{c}}$ & 0.0077 \\
\hline CASH_DEAL & $0.1584^{\mathrm{a}}$ & 0.0422 & & & & \\
\hline SHARE_DEAL & $-0.0811^{\mathrm{c}}$ & 0.0456 & -0.2199 & 0.2723 & -0.3113 & 0.2786 \\
\hline PUB_PUB & 0.0076 & 0.0544 & & & & \\
\hline PRIV_PUB & -0.0044 & 0.0542 & 0.0775 & 0.1508 & 0.0011 & 0.1389 \\
\hline DOMESTIC & -0.0164 & 0.0324 & 0.1701 & 0.1556 & 0.1115 & 0.1304 \\
\hline HOSTILE & 0.1927 & 0.1200 & $0.3288^{\mathrm{b}}$ & 0.1668 & $0.3581^{\mathrm{c}}$ & 0.1847 \\
\hline IND_MATCH & -0.0053 & 0.0428 & & & & \\
\hline AUCTION & & & & & -0.2162 & 0.3709 \\
\hline CONSTANT & $0.2882^{\mathrm{a}}$ & 0.1364 & -0.6354 & 0.5400 & -0.5355 & 0.5121 \\
\hline
\end{tabular}


Table 8 (Cont'd)

\begin{tabular}{lccc}
\hline Industry fixed-effect & Yes & Yes & Yes \\
Year fixed-effect & Yes & Yes & Yes \\
F-statistics & $4.27^{\mathrm{a}}$ & 0.94 & 0.98 \\
P-value of F-statistics & 0.00 & 0.5446 & 0.4856 \\
$\mathrm{R}^{2}$ & 0.2371 & 0.1302 & 0.1393 \\
No. of Obs. & 263 & 216 & 216 \\
\hline
\end{tabular}


Table 9 The effect of aggregative economic conditions

This table presents the estimates for effect of aggregative economic conditions on the relationship between financial bidders and deal bid premiums. The dependent variables are first (in Model 1) and final (in Model 2) bid premiums. All variables are defined in Appendix. Industry and year fixed-effect are controlled. Standard errors are adjusted for heteroscedasticity. ${ }^{\mathrm{a}},{ }^{\mathrm{b}},{ }^{\mathrm{c}}$ indicate the significance of coefficients and $\mathrm{F}$ statistics at the one, five and ten percent level respectively.

\begin{tabular}{|c|c|c|c|c|}
\hline \multirow[b]{2}{*}{ Variables } & \multicolumn{2}{|c|}{ Model 1} & \multicolumn{2}{|c|}{ Model 2} \\
\hline & Coefficient & $\begin{array}{c}\text { Std. } \\
\text { Error }\end{array}$ & Coefficient & $\begin{array}{c}\text { Std. } \\
\text { Error }\end{array}$ \\
\hline POSSIBLE_OFFER & $0.1899^{\mathrm{c}}$ & 0.1003 & $0.1954^{b}$ & 0.0988 \\
\hline FIN_BIDDER & 0.3506 & 0.3650 & 0.3461 & 0.3593 \\
\hline CREDIT_SPREAD & $24.5626^{\mathrm{b}}$ & 11.3966 & 13.7929 & 8.9665 \\
\hline FIN_BIDDER $*$ CREDIT_SPREAD & -0.5827 & 0.5644 & -0.5038 & 0.5489 \\
\hline LN(TARGET_SIZE) & -0.0132 & 0.0321 & 0.0092 & 0.0307 \\
\hline LEVERAGE & 0.0372 & 0.2485 & -0.0066 & 0.2494 \\
\hline \multicolumn{5}{|l|}{ ROA } \\
\hline Q_RATIO & -0.0265 & 0.0383 & -0.0330 & 0.0386 \\
\hline \multicolumn{5}{|l|}{ HHI } \\
\hline TOEHOLD & $-0.0104^{\mathrm{c}}$ & 0.0061 & $-0.0118^{\mathrm{c}}$ & 0.0061 \\
\hline \multicolumn{5}{|l|}{ CASH_DEAL } \\
\hline SHARE_DEAL & $-0.2612^{\mathrm{c}}$ & 0.1530 & -0.2391 & 0.1500 \\
\hline \multicolumn{5}{|l|}{ PUB_PUB } \\
\hline PRIV_PUB & $-0.2790^{\mathrm{c}}$ & 0.1429 & $-0.2741^{b}$ & 0.1410 \\
\hline DOMESTIC & $0.2066^{\mathrm{b}}$ & 0.0946 & $0.2073^{\mathrm{b}}$ & 0.0923 \\
\hline HOSTILE & -0.3830 & 0.3670 & -0.1589 & 0.3291 \\
\hline \multicolumn{5}{|l|}{ IND_MATCH } \\
\hline POST_REFORM & $-5.8518^{b}$ & 2.8209 & -3.1862 & 2.2172 \\
\hline CONSTANT & $-12.8240^{\mathrm{b}}$ & 5.9016 & -7.3507 & 4.6526 \\
\hline Industry fixed-effect & Yes & & Yes & \\
\hline Year fixed-effect & Yes & & Yes & \\
\hline F-statistics & $1.45^{\mathrm{c}}$ & & $1.46^{\mathrm{c}}$ & \\
\hline P-value of F-statistics & 0.06 & & 0.06 & \\
\hline $\mathrm{R} 2$ & 0.0778 & & 0.0746 & \\
\hline No. of Obs. & 641 & & 641 & \\
\hline
\end{tabular}




\section{Reference}

Ahern, K. R., and D. Sosyura. 2014. "Who Writes the News? Corporate Press Releases during Merger Negotiations." Journal of Finance 69 (1):241-91. doi: 10.1111/jofi.12109.

Aktas, N., E. de Bodt, and R. Roll. 2010. "Negotiations under the threat of an auction." Journal of Financial Economics 98 (2):241-55. doi: 10.1016/j.jfineco.2010.06.002.

Alperovych, Y, D. Cumming, and A. P. Groh. 2016. "M\&A rumors: Why sellers hate them." Working paper.

Alexandridis, G., K. P. Fuller, L. Terhaar, and N. G. Traylos. 2013. "Deal size, acquisition premia and shareholder gains." Journal of Corporate Finance 20:1-13. doi: 10.1016/j.jcorpfin.2012.10.006.

Ambrose, B. W., and W. L. Megginson. 1992. "The Role of Asset Structure, Ownership Structure, and Takeover Defenses in Determining Acquisition Likelihood." Journal of Financial and Quantitative Analysis 27 (4):575-89. doi: Doi 10.2307/2331141.

Armour, J., S. Deakin, and S. J. Konzelmann. 2003. "Shareholder primacy and the trajectory of UK corporate governance." British Journal of Industrial Relations 41 (3):531-55. doi: Doi 10.1111/14678543.00286 .

Bates, T. W., and M. L. Lemmon. 2003. "Breaking up is hard to do? An analysis of termination fee provisions and merger outcomes." Journal of Financial Economics 69 (3):469-504. doi: 10.1016/S0304405x(03)00120-X.

Bebchuk, L., A. Cohen, and C. C. Y. Wang. 2014. "Golden Parachutes and the Wealth of Shareholders." Journal of Corporate Finance 25:140-54. doi: 10.1016/j.jcorpfin.2013.11.008.

Betton, S., B. E. Eckbo, R. Thompson, and K. S. Thorburn. 2014. "Merger Negotiations with Stock Market Feedback." Journal of Finance 69 (4):1705-45. doi: 10.1111/jofi.12151.

Betton, S., B. E. Eckbo, and K. S. Thorburn. 2009. "Merger negotiations and the toehold puzzle." Journal of Financial Economics 91 (2):158-78. doi: 10.1016/j.jfineco.2008.02.004.

Boone, A. L., and J. H. Mulherin. 2007. "How are firms sold ?" Journal of Finance 62 (2):847-75. doi: DOI 10.1111/j.1540-6261.2007.01225.x.

Chou, H. I., G. Y. Tian, and X. K. Yin. 2015. "Takeover rumors: Returns and pricing of rumored targets." International Review of Financial Analysis 41:13-27. doi: 10.1016/j.irfa.2015.05.006.

Cumming, D., S. Ji, S. Johan, and M. Tarsalewska. 2016. "Manipulation and M\&As." Working paper.

Cumming, D., and D. Li. 2011. "Run-up of Acquirer's Stock in Public and Private Acquisitions." Corporate Governance: an International Review 19 (3):210-39. doi: 10.1111/j.14678683.2010.00838.x.

Dennis, D. K., and J. J. Mcconnell. 1986. "Corporate-Mergers and Security Returns." Journal of Financial Economics 16 (2):143-87. doi: Doi 10.1016/0304-405x(86)90059-0.

Fidrmuc, J. P., P. Roosenboom, R. Paap, and T. Teunissen. 2012. "One size does not fit all: Selling firms to private equity versus strategic acquirers." Journal of Corporate Finance 18 (4):828-48. doi: 10.1016/j.jcorpfin.2012.06.006.

Gaspar, J. M., M. Massa, and P. Matos. 2005. "Shareholder investment horizons and the market for corporate control." Journal of Financial Economics 76 (1):135-65. doi: 10.1016/j.jfineco.2004.10.002. 
Giot, P., and A. Schwienbacher. 2007. "IPOs, trade sales and liquidations: Modelling venture capital exits using survival analysis." Journal of Banking and Finance 31 (3):679-702. doi: 10.1016/j.jbankfin.2006.06.010.

Gorbenko, A. S., and A. Malenko. 2014. "Strategic and Financial Bidders in Takeover Auctions." Journal of Finance 69 (6):2513-55. doi: 10.1111/jofi.12194.

Hansen, R. G. 2001. "Auctions of companies." Economic Inquiry 39 (1):30-43. doi: DOI 10.1093/ei/39.1.30.

Harford, J., M. Humphery-Jenner, and R. Powell. 2012. "The sources of value destruction in acquisitions by entrenched managers." Journal of Financial Economics 106 (2):247-61. doi: 10.1016/j.jfineco.2012.05.016.

Harrington, J. E., and J. Prokop. 1993. "The Dynamics of the Free-Rider Problem in Takeovers." Review of Financial Studies 6 (4):851-82. doi: DOI 10.1093/rfs/6.4.851.

Holmstrom, B., and B. Nalebuff. 1992. "To the Raider Goes the Surplus? A Reexamination of the FreeRider Problem." Journal of Economics \& Management Strategy 1 (1):37-62. doi: DOI 10.1111/j.14309134.1992.00037.x.

Humphery-Jenner, M., Z. Sautner, and J. A. Suchard. 2017. "Cross-Border Mergers and Acquisitions: The Role of Private Equity Firms." Strategic Management Journal 38 (8):1688-700. doi: 10.1002/smj.2623.

Jarrell, G. A., and A. B. Poulsen. 1989. "Stock Trading before the Announcement of Tender Offers Insider Trading or Market Anticipation." Journal of Law Economics and Organization 5 (2):225-48.

Kaplan, S. N., and A. Schoar. 2005. "Private equity performance: Returns, persistence, and capital flows." Journal of Finance 60 (4):1791-823. doi: DOI 10.1111/j.1540-6261.2005.00780.x.

Kester, W. C., and T. A. Luehrman. 1995. "Rehabilitating the Leveraged Buyout." Harvard Business Review 73 (3):119-30.

King, M. R. 2009. "Prebid Run-Ups Ahead of Canadian Takeovers: How Big Is the Problem?" Financial Management 38 (4):699-726. doi: DOI 10.1111/j.1755-053X.2009.01053.x.

Martynova, M., and L. Renneboog. 2008. "A century of corporate takeovers: What have we learned and where do we stand?" Journal of Banking and Finance 32 (10):2148-77. doi: 10.1016/j.jbankfin.2007.12.038.

Moeller, S. B., F. P. Schlingemann, and R. M. Stulz. 2004. "Firm size and the gains from acquisitions." Journal of Financial Economics 73 (2):201-28. doi: 10.1016/j.jfineco.2003.07.002.

Mulherin, H., and S. A. Simsir. 2015. "Measuring Deal Premiums in Takeovers." Financial Management 44 (1):1-14. doi: 10.1111/fima.12053.

Payne, J. 2011. "Minority shareholder protection in takeovers: A UK perspective." European Company and Financial Law Review 8 (2):145-173. doi: https://doi.org/10.1515/ecfr.2011.145.

Renneboog, L., T. Simons, and M. Wright. 2007. "Why do public firms go private in the UK? The impact of private equity investors, incentive realignment and undervaluation." Journal of Corporate Finance 13 (4):591-628. doi: DOI 10.1016/j.jcorpfin.2007.04.005. 
Restrepo, F., and G. Subramanian. 2017. "The Effect of Prohibiting Deal Protection in Mergers and Acquisitions: Evidence from the United Kingdom." Journal of Law and Economics 60 (1):75-113. doi: $10.1086 / 692585$.

Sanders, R. W., and J. S. Zdanowicz. 1992. "Target Firm Abnormal Returns and Trading Volume around the Initiation of Change in Control Transactions." Journal of Financial and Quantitative Analysis 27 (1):109-29. doi: Doi 10.2307/2331301.

Schwert, G. W. 2000. "Hostility in takeovers: In the eyes of the beholder?" Journal of Finance 55 (6):2599-640. doi: Doi 10.1111/0022-1082.00301.

Takeover Panel. 2011. "The Takeover Code, RR Donnelley."

Takeover Panel. 2011. "Review of certain aspects of the regulation of takeover bids."

Van Bommel, J. 2003. "Rumors." Journal of Finance 58 (4):1499-519. doi: 10.1111/1540-6261.00575. 
